\title{
THE EFFECT OF COMPANY SIZE, SALES GROWTH, CURRENT RATIO (CR), NET PROFIT MARGIN (NPM) AND RETURN ON EQUITY (ROE) ON STOCK PRICES
}

\author{
Nursiam ${ }^{1}$, Vicky Sari Rahayu ${ }^{2}$ \\ Faculty of Economics and Business \\ Universitas Muhammadiyah Surakarta \\ E-mail: nur183@ums.ac.id
}

\begin{abstract}
This research focuses on how several internal factors influence the company's stock prices through the company analysis and based on previous studies that have often been done with no consistent results. The purpose of this research is to analyze the size of the company, sales growth, CR, NPM and ROE as a review of the company's share prices on the Indonesia Stock Exchange's LQ45 Index. This research used a purposive sampling technique. Before employing the data analysis, a classic assumption test was performed. The hypothesis testing was carried out using multiple regression analysis. The results showed that the size of the company, sales growth, the NPM, and the ROE affect the stock prices, whereas the CR does not affect stock prices.
\end{abstract}

Keywords: current ratio, company size, net profit margin, return on equity (ROE), sales growth, stock price.

\section{INTRODUCTION}

According to Jogiyanto (2015), a company may sell its ownership rights in the form of stocks. Stock investment is one of the most popular securities traded in the capital market. Stock prices are volatile and fluctuating although investors always expect a high rate. Therefore, investors need some information from the company to be considered, particularly accurate details on stock investments in the capital market. One of the reliable and accessible information from the company is a financial report published on the stock exchange.

Some factors that can influence the fluctuation of the stock prices include: internal factors; these factors are from inside the company and specifically related to stocks, such as sales, financial performance, management performance, as well as the condition of the company and the industry in which the company is engaged. Meanwhile, the other factors are external factors; these are macro factors that influence the stock prices on the stock exchange, such as inflation, interest rates, foreign exchange rates, and non-economic factors like social, political and other factors.

The study by Ginantra and Putra (2015) shows that big companies tend to obtain more attention from analysts, investors, 
and the government. The size of the company is in line with the amount of fund endowed by investors. To do so, the company issues stocks in accordance with the price determined from the supply and demand in the capital market.

Sales growth is a change in sales over the years. If sales growth from year to year always rises, the company may have good prospects in the future (Novitasari and Dini, 2015). It indicates that sales growth influences the stock prices as it may attract investors to invest resulting in the increase of the stock prices due to the demand. This finding is empirically substantiated by Rini (2016). However, the studies by Rahmandia (2013) and Clarensia, et al. (2011) show the opposite- sales growth does not affect the stock prices. The high value of Current Ratio (CR) may attract many investors to participate by buying stocks from the company; this eventually instigates the stock price to rise. It shows that $\mathrm{CR}$ has a positive effect on the stock prices as explained in Rosmiati (2016). On the other hand, Rani and Diantini (2015) and Tumandung, et al. (2017) argue that $\mathrm{CR}$ does not have a significant effect on stock prices.

The higher the Net Profit Margin (NPM) is better because it shows that the company's ability to earn profits through sales and reduce costs is relatively high. It, hence, triggers the company's stock prices to increase as it will lead to investors' confidence to invest in the company. This notion is in accordance with Hutami (2012) who states that NPM has a significant influence on the stock prices. However, it is different from Salsabila (2017) who argues that NPM does not determine the stock prices.

According to Chrisna (2011), the increase in Return on Equity (ROE) is often followed by an increase in the company's stock prices. ROE has a significant effect on the stock prices as explained in Hutami (2012); yet, ROE does not affect the stock prices according to Deitiana (2011) and Wilianto (2012).

According to the background as mentioned earlier, this study aims at determining the effect of Company Size, Sales Growth, CR, NPM and ROE on Stock Prices (Empirical Study on LQ 45 Index Companies Listed on the Indonesia Stock Exchange 2014-2017).

\section{LITERATURE REVIEW}

According to Jogiyanto (2014), any information published as a notice will provide a signal for investors in making investment decisions. It is because the info essentially presents reports and descriptions of the past, present, and future conditions of the company. Mardiyah (2002) posits that company size is a scale of a company which can be classified according to various methods, including total assets, stock market value, etc. The higher the size of a company the more a company excels its wealth and performance. Hence, it will attract investors to trust and invest their capital by buying the company'shares; this will ultimately make the stock prices raise.

Sales growth is defined as an increase in the number of sales from year to year or from time to time (Kennedy and Anisa, 2013). The higher the level of sales indicates 
that the financial condition of the company is good. Kusumajaya (2011) suggests that the company's growth rate as measured by sales growth affects the company's stock prices as the company's growth is a sign of an excellent corporate development that leads to a positive response from investors.

The type of liquidity ratio used is Current Ratio (CR) is a ratio employed to measure the company's ability to pay its short-term liabilities or debts before the due date when billed as a whole. Meanwhile, according to Kasmir (2011) CR is a ratio that measures a company's ability to pay off almost overdue debts. Net Profit Margin (NPM) measures the size of the company's net profit compared to its sales. High NPM shows good company performance as it can generate a large amount of net income through its sales activities. Besides, the company can also reduce its costs satisfactorily. As a result, the company's shares are in high demand and will eventually increase the company's stock prices (Ardin, 2005: 37). Return On Equity (ROE) is a ratio used to measure the ability of the company to be able to generate a net income based on individual equity; this ratio is a measure of profitability from the perspective of the shareholders. The higher the ROE level of the company the higher the ability of the company to generate more profits; thus, it may lead to higher stock prices.

Investors will be attracted to invest their capital in companies that own a large number of assets. It triggers the escalation of the stock prices. This notion is supported by
Rahmandia (2013) and Zaki, et al. (2017) who explain that the size of the company has a positive effect on the stock prices. H1: Company size affects the stock prices

The positive trend in sales growth may cause the escalation of the investors'interest in buying the company's shares; thus, the stock prices will continue to go up. It is in line with Clarensia et al. (2011) who convey that liquidity, profitability, sales growth, and dividend policy simultaneously influence the stock prices. H2: Sales growth influences the stock prices

The better the $\mathrm{CR}$ value, the more liquid the company is, so that it may increase the public's interest in investing in the company; this will gain a positive impact on the stock prices (Deitiana, 2013). Sutapa (2018) and Rosmiati (2016) agree with this view as they imply that CR has a positive effect on stock prices. H3: CR affects the stock prices

High NPM may indicate a good company performance as it can give rise to a significant amount of net income through its sales activities. Hence, the company's shares are in high demand which may lead to an increase in the company's stock prices (Ardin, 2005). It is supported by Hutami (2012). She states that NPM has a positive and significant effect on stock prices. H4: NPM affects the stock prices

The high value of ROE implies a decent performance of the company in managing its capital to make profits for its shareholders. Therefore, it can be concluded that the connection between ROE and stock price is constructive. It is 
supported by Hutami (2012), Rosmiati (2016), and Sutapa (2018) who argue that ROE has a positive and significant effect on the stock prices. H5: ROE affects the stock prices

\section{METHOD}

This study employed a quantitative approach that used secondary data. The data were obtained from financial reports of LQ 45 Index companies listed on the Indonesia Stock Exchange (IDX) from 2014 to 2017. The data were accessed at www.idx.co.id. The population of this study was companies listed as LQ 45 Index on the Indonesia Stock Exchange from 2014 to 2017. A purposive sampling method was employed to obtain representative samples according to the criteria determined by the researcher. The criteria were as follow: (a) Companies that published audited financial statements for the 2014-2017 period, (b) Companies that were consistently listed in the LQ 45 Index for the period 20142017, (c) Companies that presented financial reports in IDR, (d) LQ 45 Index companies that presented financial reports according to the examined variables.

The size of the company is a scale to determine how big the company seen in various ways, i.e., total assets, stock market values, etc. (Widana and Gerianta, 2013). The following formula is used to assess the size of the company: Company Size $=$ Ln Total Assets

Clarensia and Azizah (2011) state that sales growth is an increase in the number of sales from year to year or from time to time. The formula of sales growth is composed as follows:

$$
\text { Sales Growth }=\frac{\text { Sales }_{1}-\text { Sales }_{\mathrm{t}-1}}{\text { Sales } \mathrm{t}-1}
$$

Sales $_{1}$ is total sales for the current period. Salest-1 is total sales for the last period

Current Ratio (CR) is a ratio employed to measure the company's ability to pay its short-term liabilities or debts before the due date when billed as a whole (Sutapa, 2018). The formula of this variable can be written as follows:

$$
\mathrm{CR}=\frac{\text { Current Asset }}{\text { Current Debt }}
$$

According to Rinati (2001), NPM shows how much a percentage of a net profit is earned from each sale. Besides, Tandelilin (2008) explains that the value for NPM is calculated by dividing the net income after tax by the total sales; the formula can be noticed below:

$$
\text { NPM }=\frac{\text { Net Income after Tax }}{\text { Total Sales }}
$$

ROE is a ratio used to find out the company's ability to produce a net income based on a particular capital share; this ratio is one profitability measurements from the perspective of the shareholders. According to Mardiyanto (2009), the formula of the ROE variable is written as follows:

$$
\mathrm{ROE}=\frac{\text { Net Income after Tax }}{\text { Total Equity }}
$$


The dependent variable used in this study is the stock prices. Stock prices are the prices at which the stocks are traded based on the supply and demand in the capital market. Hence, in this study, the stock prices used are the prices at the closing time (Closing Price). An analysis was carried out to test the relationship between several independent variables and the dependent variable using multiple regression tests. The regression equation to test the proposed hypotheses is stated in the following model:

$$
\begin{gathered}
\mathrm{Y}=\alpha+\beta 1 \mathrm{X} 1+\beta 2 \mathrm{X} 2+\beta 3 \mathrm{X} 3+ \\
\beta 4 \mathrm{X} 4+\beta 5 \mathrm{X} 5+\varepsilon
\end{gathered}
$$

While $\mathrm{Y}$ is stock price, $\alpha$ is constant, $\beta 1-\beta 5$ is coefficient of each variable, $\mathrm{X} 1$ is size, $\mathrm{X} 2$ is sales growth, $\mathrm{X} 3$ is $\mathrm{CR}, \mathrm{X} 4$ is NPM, $\mathrm{X} 5$ is ROE, and $\varepsilon$ is error

\section{RESULT AND DISCUSSIONS}

Table 1. Multiple Linear Regression Test Results

\begin{tabular}{lllll}
\hline \multicolumn{1}{c}{ Variables } & \multicolumn{1}{c}{$\begin{array}{c}\text { Regression } \\
\text { Coefficients }\end{array}$} & $\mathrm{t}_{\text {count }}$ & Sig & Notes \\
\hline Constant & -32303.203 & -2.286 & 0.025 & - \\
Company Size & 1142.146 & 2.542 & 0.013 & $\mathrm{H}_{1}$ accepted \\
Sales Growth & -3582.847 & -2.223 & 0.029 & $\mathrm{H}_{2}$ accepted \\
Current Ratio (CR) & -247.822 & -1.019 & 0.312 & $\mathrm{H}_{3}$ rejected \\
Net Profit Margin (NPM) & -13038.735 & -4.379 & 0.000 & $\mathrm{H}_{4}$ accepted \\
Return On Equity (ROE) & 27787.908 & 16.005 & 0.000 & $\mathrm{H}_{5}$ accepted \\
\hline
\end{tabular}

$\mathrm{R}^{2}=0.804 \quad$ Adjusted $\mathrm{R}^{2}=0.790 \quad \mathrm{~F}_{\text {count }}=59.060$

Source: Secondary Data Processed with SPSS

From the calculation results for the adjusted R2 value with the assistance of the SPSS program in the multiple regression analysis, the coefficient of determination or adjusted $\mathrm{R} 2$ is 0.790 . It indicates that $79 \%$ of the variations of the variables in the stock prices are explained by the company size, sales growth, CR, NPM, and ROE. Whereas the remaining $21 \%$ is explained by other factors apart from the studied model.

From the test result, it is shown that the $F$ value is 59.060 and the probability value ( $\mathrm{p}$-value) is 0.000 , which denotes a significance level at $5 \%(0.000<0.05)$. It, therefore, can be interpreted that the independent variables comprising company size, sales growth, CR, NPM, and ROE jointly affect the dependent variable (stock prices). In other words, the model used in this study is the right one (goodness of fit model).

The t-test was used to determine the effect of each independent variable on the dependent variable. The test results of each hypothesis are presented in table 1. From the scores obtained from the t-test, it can be seen that: (a) the value of the $t_{\text {count }}$ for the Company Size variable is 2.542 , and the significance value is $0.013<0.05$; in other words, H1 is accepted-this shows that Company Size affects the 
stock prices. (b) the score of $t_{\text {count }}$ for the Sales Growth variable is -2.223 and the significance level is $0.029<$ 0.05 ; thus, $\mathrm{H} 2$ is accepted. Thus, Sales Growth influences stock prices, (c) the score of $t_{\text {count }}$ for $C R$ variable is -1.1019 and the significance level is $0.312>0.05$; this means that $\mathrm{H}_{3}$ is rejected; in other words, $C R$ does not sway the stock prices, (d) the score of $\mathrm{t}_{\text {count }}$ for $N P M$ is -4.379 and the significance level is $0.000<0.05$ so that $\mathrm{H}_{4}$ is accepted. It denotes that $N P M$ sways the stock prices, and (e) the score of $\mathrm{t}_{\text {count }}$ for variable $R O E$ is 16.005 , and the significance level is $0.000>0.05$; therefore, $\mathrm{H}_{5}$ is accepted. It means that $R O E$ affects the stock prices.

The regression coefficient of the company size variable is 1142.146; this shows a positive value with a significance value of 0.013 . As the significance value is smaller than $0.05, \mathrm{H} 1$ is accepted. It indicates a significant result which means that the company size influences the stock price. The large size of the company is a signal that may become a consideration for the investors before deciding on the stock investment. The more investors are interested in the company, the more demand that occurs for the shares of the company. Further, it may also cause the rise of the stock prices. Consequently, this study finds out that the company size influences the stock prices as supported by Rahmandia (2013) and Zaki, et al. (2017).

The regression coefficient of the sales growth variable is 3582.847 (this is negative); besides, the significance value is 0.029 . Because the significance value is smaller than $0.05, \mathrm{H} 2$ is accepted. It illustrates that sales growth affect the stock prices. Companies that have high sales will also increase their profits. The sales growth, henceforth, may become one aspect to be considered by the investors due to its prospects in the future. Reflecting on this perception, the demand for shares in the capital market will escalate. As results, there will be a rise in the stock prices. To sum up, the results of this study depicts that sales growth affects the stock prices. It is in line with Rini (2016).

The regression coefficient of $\mathrm{CR}$ variable is -247.822 , which is negative, and the significance value is 0.312 . Since its significance value is greater than $0.05, \mathrm{H} 3$ is rejected. It tells that CR does not affect the stock prices. CR is usually able to show the occurrence of a problem at the level of liquidity if it has a low value as the company is considered unable to fulfill its current obligations using its current assets. Therefore, CR value does not affect the increase or decrease in the stock prices. To conclude, the results of this study show that CR does not affect the stock prices. It is similar to the findings of Rani and Diantini (2015) and Tumandung, et al. (2017).

The regression coefficient of NPM variable shows -13038.735 (negative); and, the significance value is 0.000 . Because the significance value is smaller than $0.05, \mathrm{H} 4$ is accepted. It means that NPM affects the stock prices. According to Tandelilin (2008), NPM is calculated by dividing the net income after tax by the total sales. NPM can determine the company's ability to reduce costs in 
order to generate more profits through sales. Thus, the high value of NPM may act as a signal to the investors, so that they are interested in investing their money with a big demand for shares in the company. Further, the demand in many capital markets may result in the upsurge of the stock prices. So, it can be concluded that NPM affects stock prices. Moreover, this corresponds to Hutami (2012).

The regression coefficient of ROE variable shows a positive value of 27787.908 and significance value of 0,000 . Because the significance value is smaller than $0.05, \mathrm{H} 5$ is accepted. It means that ROE affects stock prices. The ROE ratio can be calculated by dividing the net income by the total equity of the company (Tandelilin, 2017). This indicator is considered essential to finding out the extent to which the investments can provide an appropriate return. It makes every change in the value of ROE attracts investors. Consequently, the demand for the investment also grows causing the changes in the company's stock prices. Following the results of this study, it is concluded that ROE

\section{REFERENCES}

Ardin, Sianipar. 2005. "Pengaruh faktor fundamental terhadap harga saham industri perbankan di indonesia". Thesis Magister Akuntansi Pascasarjana Universitas Sumatera Utara.

Chrisna, Heriyati. 2011. "Pengaruh roe, net interest margin, dan deviden payout ratio terhadap harga saham perbankan di bursa efek indonesia". Thesis Magister affects the stock prices. It is in line with Hutami (2012).

\section{CONCLUSION}

Based on the results of the study, it can be concluded that company size, sales growth, NPM, and ROE influence the stock prices of LQ45 Companies Listed on the Indonesia Stock Exchange from 2014 to 2017. Meanwhile, CR does not affect the stock prices.

This study has several limitations, namely: (1) the focus of this study is only on internal factors through a company analysis. Therefore, it overlooks external factors from outside the company that may affect the stock prices, (2) this study only used limited financial ratio variables

This study has the following suggestions: (1) Adding variables from external factors that may affect the stock prices as well as adding other financial ratios to independent variables, (2) For companies and investors, further researchers should pay attention to company size and sales growth in conducting NPM and ROE analysis because these variables can affect the stock prices.

\section{Akuntansi Pascasarjana Universitas Sumatera Utara.}

Clarensia, Jeany., S. Rahayu., \& N. Azizah. 2011. "Pengaruh likuiditas, profitabilitas pertumbuhan penjualan dan kebijakan dividen terhadap harga saham". Jurnal Fakultas Ekonomi Universitas Budi Luhur Jakarta.

Deitiana, T. 2013. "Pengaruh CR, $\mathrm{ROE}$, dan total assets turnover 
terhadap dividend payout ratio dan implikasi pada harga saham perusahaan LQ 45\%. Jurnal Bisnis dan Akuntansi. Vol.1 No.15. Pp. 81-88.

Ginantra, I.K.G., \& I.N.W.A. Putra. 2015. "Pengaruh profitabilitas, leverage, ukuran perusahaan, kepemilikan publik, dpr dan npm pada perataan laba". Ejurnal Akuntansi Universitas Udayana. Vol.2 No.10. pp. 602-617.

Hutami, Rescyana Putri. 2012. "Pengaruh DPR, ROE dan NPM terhadap harga saham perusahaaan industri manufaktur yang tercatat di bursa efek indonesia periode 2006-2010". Jurnal Nominal: Vol I, NoI.

Jogiyanto. 2014. Teori portofolio dan analisis investasi (edisi kesembilan). Yogyakarta: BPFE.

Jogiyanto. 2015. Teori Portofolio dan Analisis Investasi (Edisi Kesepuluh). Yogyakarta: BPFE.

Kasmir. 2011. Analisis laporan keuangan. Jakarta: Rajawali Pers

Kennedy, Nur Azlina \& Anisa R.S. 2013. "faktor-faktor yang mempengaruhi struktur modal pada perusahaan real estate and property yang go public di bursa efek indonesia". Jurnal Akuntansi Fakultas Ekonomi Universitas Riau.

Kusumajaya, D.K. Oka. 2011. "Pengaruh struktur modal dan pertumbuhan perusahaan terhadap profitabilitas dan nilai perusahaan pada perusahaan manufaktur di bursa efek indonesia”. Thesis Pascasarjana Universitas Udayana.

Mardiyah, Aida Ainul. 2002. "Pengaruh asimetri informasi dan disclosure terhadap cost of capital. Jurnal Riset Akuntansi

Indonesia. Vol. 5, pp 225-229.

Mardiyanto, Handono. 2009. Inti sari manajemen keuangan (teori, soal, dan jawaban). Jakarta: Grasindo.

Novitasari, Bunga., \& Dini Widyawati. 2015. "Pengaruh profitabilitas, pertumbuhan penjualan dan kebijakan dividen terhadap harga saham". Jurnal Ilmu \& Riset Akuntansi. Vol.4 No.2 Pp.1-17.

Rahmandia, Febian. 2013. "Faktorfaktor yang mempengaruhi harga saham perusahaan disektor barang industri konsumsi yang terdaftar di bei periode 20072011". Jurnal Ilmiah Mahasiswa Universitas Surabaya. Vol.2 No.1

Rani, Kadek Stia \& N N A. Diantini. 2015. "Pengaruh Kinerja Keuangan Perusahaan Terhadap Harga Saham dalam Indeks LQ45 di BEI". Ejurnal Manajemen Unud. Vol 4 No 6.

Rinati, Ina. 2001. "Pengaruh NPM, ROA dan ROE terhadap harga saham perusahaan yang tercantum dalam Indeks LQ45". Jurnal Ekonomi dan Manajemen. Vol.1 No.2 Pp. 19-131.

Rini, Erlin Puspita. 2016. "Pengaruh arus kas, kebijakan deviden dan pertumbuhan penjualan terhadap harga saham". Skripsi Universitas Muhammadiyah Surakarta.

Rosmiati., \& Heru Suprihhadi. 2016. "Pengaruh kinerja keuangan terhadap harga saham pada perusahaan makanan dan minuman". Jurnal Ilmu Dan Riset Manajemen. Vol 5, No 2.

Sutapa., Nyoman. I. 2018. "Pengaruh rasio dan kinerja keuangan 
terhadap harga saham pada indeks LQ 45 di BEI Periode 2015-2016". Jurnal Krisna: Kumpulan Riset Akuntansi; Vol.9 No.2 Pp. 11-19.

Tandelilin, E. 2008. Analisis investasi dan manajemen portofolio. Yogyakarta: BPFE.

Tandelilin, E. 2017. Pasar modal, manajemen portofolio \& investasi. Yogyakarta: PT Kanisius.

Widana, I.N. Ari dan Gerianta W.Y. 2013. "Perataan laba serta faktor- faktor yang mempengaruhinya di bursa efek indonesia". E-Jurnal Akuntansi Universitas Udayana. Vol.3 No.2 Pp: 297-317.

Zaki, Muhammad., Islahuddin., \& M. Shabri. 2017. "Pengaruh profitabilitas, leverage keuangan dan ukuran perusahaan terhadap harga saham (studi pada perusahaan manufaktur yang terdaftar di bei periode 20052014)". Jurnal Megister Akuntansi. Vol.6 No.2 Pp 58-66. 